\title{
The Potential Use of Persian Herbal Medicines Against COVID-19 Through Angiotensin-Converting Enzyme 2
}

\author{
Fatemeh Heidary ${ }^{1,{ }^{*}}$, Mehran Varnaseri ${ }^{2}$ and Reza Gharebaghi ${ }^{3}$ \\ ${ }^{1}$ Head of Ophthalmology Division, Taleghani Hospital, Padad Shahr, Ahvaz Jundishapur University of Medical Sciences, Ahvaz, Iran \\ ${ }^{2}$ Infectious Diseases Department, Razi Hospital, Ahvaz Jundishapur University of Medical Sciences, Ahvaz, Iran \\ ${ }^{3}$ Kish International Campus, University of Tehran, Tehran, Iran \\ "Corresponding author: Taleghani Hospital, Ahvaz Jundishapur University of Medical Sciences, Ahvaz, Iran. Email: drfatemehheidari@yahoo.com
}

Received 2020 March 18; Accepted 2020 March 24

Keywords: COVID-19, Angiotensin-Converting Enzyme 2

\section{Dear Editor,}

The outbreak of the new coronavirus disease (COVID19) was reported from Wuhan City, China in December 2019 (1-3) and subsequently affected many countries worldwide; sparkling a pandemic.

The COVID-19 is an enveloped positive stranded RNA virus and initial studies indicate that the virus is phylogenetically related to the SARS-Corona viruses (4). It is also said that these two viruses share a similar receptor, called angiotensin-converting enzyme 2 (ACE2), to enter the host cell $(5,6)$.

It has been revealed that four receptors are known for ACE2, with the majority of its biological activities being carried out by type I and type II receptors called AT1R and AT2R, respectively. In the lung, AT1R has been identified in alveolar macrophages, alveolar type II cells, bronchiolar epithelial cells, vascular smooth muscle cells, endothelial cells, and fibroblasts; whereas, AT2R has been identified in airway epithelial cells associated with dense staining of the brush border, some mucous glands, vascular endothelial cells, fibroblasts, chondrocytes and macrophages (7-10).

In a recently published paper by Zhang et al. (11), theoretical therapeutic approaches suggested addressing ACE2-mediated COVID-19 infection. In brief, these include spike protein-based vaccine production, inhibition of transmembrane protease serine 2 (TMPRSS2) activity, inhibition of ACE2 receptor, and delivery of large amounts of soluble form ACE2 (11). But none have yet been definitively admitted to the clinic. However, as we are facing a fast-spreading virus worldwide, there is a need for simple, inexpensive, and affordable treatment to address and cure this worldwide outbreak.

A few years ago, Ziai and Heidari (12) examined the 20 plant extracts and observed the largest inhibitory effect on ACE was primarily related to Cerasus avium (L.) Moench, Alcea digitata (Boiss.) Alef, and Rubia tinctorum L, up to $100 \%$. Citrus aurantium L.; Berberis integerrima Bge; Peganum harmala L.; and Allium sativum L also showed an inhibitory effect up to $70 \%$ or more (12). Therefore, we suggest that these herbal products or those with similar mechanisms could be considered for the treatment of the COVID-19 outbreak following the necessary in vitro and in vivo evaluation. Furthermore, it should be noted that ACE inhibitors may cause up-regulation of its receptor and may increase susceptibility to the COVID-19 infection in the long run (13). Therefore, patients who are treated with ACE inhibitors should be excluded from these herbal remedies.

However, it should be acknowledged that since the ACE2 is low expressed in potential lung target immune cells, it is still possible for the COVID-19 to reach into its target cells using other receptors or cellular entry modes and this needs further verification (14). In the end, it is hypothesized that the pattern of the COVID-19 outbreak worldwide may be due to mutations or genetic manipulation that has caused damage to certain races and selected countries. Therefore, further studies are needed to confirm this possibility.

\section{Acknowledgments}

We appreciate technical assistant of Dr. Bahar Amini from Ahvaz Jundishapur University of Medical Sciences, Ahvaz, Iran.

\section{Footnotes}

Conflict of Interests: None. 
Funding/Support: None declared.

\section{References}

1. Wu F, Zhao S, Yu B, Chen YM, Wang W, Song ZG, et al. A new coronavirus associated with human respiratory disease in China. $\mathrm{Na}$ ture. 2020;579(7798):265-9. doi: 10.1038/s41586-020-2008-3. [PubMed: 32015508]. [PubMed Central: PMC7094943].

2. Huang C, Wang Y, Li X, Ren L, Zhao J, Hu Y, et al. Clinical features of patients infected with 2019 novel coronavirus in Wuhan, China. Lancet. 2020;395(10223):497-506. doi: 10.1016/S0140-6736(20)30183-5. [PubMed: 31986264].

3. Reviglio VE, Osaba M, Reviglio V, Chiaradia P, Kuo IC, O’Brien TP. COVID-19 and ophthalmology: A new chapter in an old story. Med Hypothesis Discov Innov Ophthalmol. 2020;9(2):71-3.

4. Habibzadeh P, Stoneman EK. The novel coronavirus: A bird's eye view. Int J Occup Environ Med. 2020;11(2):65-71. doi: 10.15171/ijoem.2020.1921. [PubMed: 32020915].

5. Lu R, Zhao X, Li J, Niu P, Yang B, Wu H, et al. Genomic characterisation and epidemiology of 2019 novel coronavirus: Implications for virus origins and receptor binding. Lancet. 2020;395(10224):565-74. doi: 10.1016/S0140-6736(20)30251-8. [PubMed: 32007145].

6. Zhou P, Yang XL, Wang XG, Hu B, Zhang L, Zhang W, et al. A pneumonia outbreak associated with a new coronavirus of probable bat origin. Nature. 2020;579(7798):270-3. doi: 10.1038/s41586-020-2012-7. [PubMed: 32015507]. [PubMed Central: PMC7095418].

7. Hamming I, Timens W, Bulthuis ML, Lely AT, Navis G, van Goor H. Tissue distribution of ACE2 protein, the functional receptor for SARS coronavirus. A first step in understanding SARS pathogenesis. JPathol. 2004;203(2):631-7. doi:10.1002/path.1570. [PubMed: 15141377].

8. Danser AH. Local renin-angiotensin systems. Mol Cell Biochem. 1996;157(1-2):211-6. doi: 10.1007/bfo0227900. [PubMed: 8739248].

9. Schulman IH, Raij L. The angiotensin II type 2 receptor: What is its clinical significance? Curr Hypertens Rep. 2008;10(3):188-93. doi: 10.1007/s11906-008-0036-8. [PubMed: 18765088].

10. Bullock GR, Steyaert I, Bilbe G, Carey RM, Kips J, De Paepe B, et al. Distribution of type-1 and type-2 angiotensin receptors in the normal human lung and in lungs from patients with chronic obstructive pulmonary disease. Histochem Cell Biol. 2001;115(2):117-24. doi: 10.1007/s004180000235. [PubMed: 11444146].

11. Zhang H, Penninger JM, Li Y, Zhong N, Slutsky AS. Angiotensinconverting enzyme 2 (ACE2) as a SARS-CoV-2 receptor: molecular mechanisms and potential therapeutic target. Intensive Care Med. 2020;46(4):586-90. doi: 10.1007/s00134-020-05985-9. [PubMed: 32125455]. [PubMed Central: PMC7079879].

12. Ziai SA, Heidari MR. Inhibitory effects of germinal angiotensin converting enzyme by medicinal plants used in Iranian traditional medicine as antihypertensive. J Kerman Univ Med Sci. 2015;16(2):13444.

13. Watkins J. Preventing a covid-19 pandemic. BMJ. 2020;368:m810. doi: 10.1136/bmj.m810. [PubMed: 32111649].

14. Prompetchara E, Ketloy C, Palaga T. Immune responses in COVID-19 and potential vaccines: Lessons learned from SARS and MERS epidemic. Asian Pac J Allergy Immunol. 2020;38(1):1-9. doi: 10.12932/AP200220-0772. [PubMed: 32105090]. 